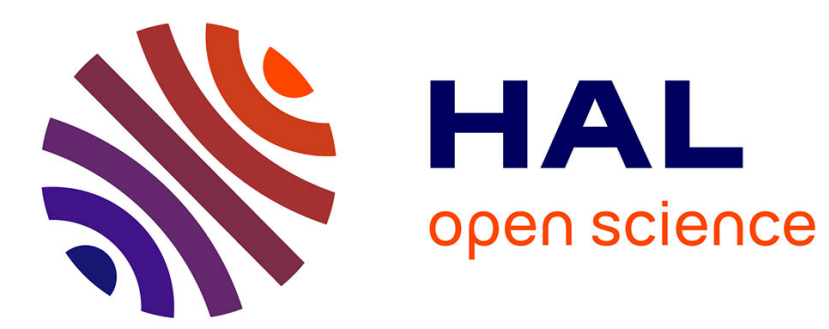

\title{
THE NONMETAL-METAL TRANSITION IN FLUIDS
}

J. Hernandez

\section{To cite this version:}

J. Hernandez. THE NONMETAL-METAL TRANSITION IN FLUIDS. Journal de Physique IV Proceedings, 1991, 01 (C5), pp.C5-367-C5-368. 10.1051/jp4:1991543 . jpa-00250670

\section{HAL Id: jpa-00250670 https://hal.science/jpa-00250670}

Submitted on 1 Jan 1991

HAL is a multi-disciplinary open access archive for the deposit and dissemination of scientific research documents, whether they are published or not. The documents may come from teaching and research institutions in France or abroad, or from public or private research centers.
L'archive ouverte pluridisciplinaire HAL, est destinée au dépôt et à la diffusion de documents scientifiques de niveau recherche, publiés ou non, émanant des établissements d'enseignement et de recherche français ou étrangers, des laboratoires publics ou privés. 


\title{
THE NONMETAL-METAL TRANSITION IN FLUIDS
}

\author{
J.P. HERNANDEZ \\ Department of Physics and Astronomy, University of North Carolina, Chapel Hill, NC 27599-3255, \\ U.S.A.
}

The non-Metal-Metal (nM-M) transition in fluids is of special interest in this colloque. It takes place as the metalatom density is increased, either intrinsically in pure $\mathrm{Cs}, \mathrm{Rb}$ or $\mathrm{Hg}$, for example, or as a function of metal-atom concentration in metal-ammonia solutions. Naturally, the role of the conduction electrons is central in the changing material properties characteristic of this transition and in affecting the interactions within the material which mediate this change in properties. Prof. Ashcroft, in his review talk here, has emphasized the "state dependence" of the interactions, i.e., the fact that all effects due to conduction electrons are intrinsically density dependent. This fact implies a selfconsistency between structure, including disorder, and electronic properties.

In my view, the self-consistency between structure and electronic effects is crucial in the $\mathrm{nM}-\mathrm{M}$ transition and must be reflected in a gradual change, as the conduction electron density increases, in coulombic screening from what may be crudely characterized as one of the Debye-Huckel type to a Fermi-Thomas one. Also, a peaking in the importance of charged clusters is probably a structural property which preceeds the $\mathrm{nM}-\mathrm{M}$ transition. These suggestions are a result of model calculations in which first screening was estimated ${ }^{1}$ and then generalizations were included ${ }^{2}$ which noted the importance of clustering effects in pure alkali-atom systems.

The experimental evidence for these type of effects has been, for example, electron solvation in dilute metal-ammonia solutions with delocalization as the metal-atom concentration increases. Prof. Hensel has reviewed here evidence for intrinsic electron self-trapping in dense $\mathrm{Hg}$ vapor: a mobility minimum and a strong, positive, thermopower peak. Direct experimental evidence for positively charged clusters is not yet available due to the lack of a local probe, in contrast to macroscopic probes such as electrical conductivity. It may be that the clear double peak which survives increasing temperature, reported here by Tamura, in the structure factor of $\mathrm{Hg}$ approaching the metal-nonmetal transition may indicate clustering effects but this data has not been analyzed from this point of view. 
Clearly there is still a distinct challenge to theorists to treat the $\mathrm{nM}-\mathrm{M}$ transition in fluids fully self-consistently with electronic and thermodynamic effects treated on the same basis. For experimentalists, a local probe remains a goal to be sought and exploited.

\section{References:}

(1) HERNANDEZ, J.P., Phys. Rev. A 34 (1986) 1316

(2) HERNANDEZ, J.P., Phys. Rev. Lett. 57 (1986) 3183 